Original Article

\title{
Undiagnosed Hypertension and Proteinuria in a Market Population in Ile-Ife, Nigeria
}

\author{
Arogundade Fatiu*1,2, Sanusi Abubakr ${ }^{1,2}$, Hassan Muzamil2, Gbadegesin Aderoju ${ }^{2}$, Olarinoye \\ Funmilayo $^{2}$, Otuyemi Bola ${ }^{2}$, Akinsola Adewale ${ }^{1,2}$
}

(1) Department of Medicine, Obafemi Awolowo University and (2) Renal Unit, Department of Medicine, Obafemi Awolowo University Teaching Hospitals Complex; P.M.B 5538 Ile-Ife, Osun State, Nigeria

\begin{abstract}
Introduction: Hypertension and chronic kidney disease (CKD) are common in our urban and rural communities but the majority of affected individuals are not aware of their condition. We conducted free medical examination and screening during one of the market days in Odo-Ogbe market, Ile-Ife, Nigeria to evaluate the magnitude of undiagnosed hypertension and proteinuria.
\end{abstract}

Methods: Participants were taken through a brief medical history and had their socio-demographic data taken. Weight and height were measured and body mass index (BMI) calculated. Blood pressure (BP) was measured using a mercury sphygmomanometer and urinalysis was done with the aid of dipstick test.

Results: A total of 286 participants aged 13-90 years (Mean $49.5 \pm 15.7$ years) were screened. Females constituted $90.2 \%$ of the study population. One-hundred and eight $(37.7 \%)$ of participants had hypertension and only $20(6.7 \%)$ were previously diagnosed. Sixty-nine participants $(24.1 \%)$ had stage-1 hypertension while 39 $(13.6 \%)$ had stage-2 hypertension. Fifty-nine percent of participants had BMI above $25 \mathrm{~kg} / \mathrm{m}^{2}$. Eighty five participants $(29.7 \%)$ had proteinuria while only 13 (4.5\%) had glycosuria. A significantly higher percentage of participants with stage- 1 and stage- 2 hypertension had proteinuria compared with non hypertensives. There was a positive correlation between age and BMI $(r=0.171$, $\mathrm{P}=0.004)$, age and systolic $\mathrm{BP}(\mathrm{r}=0.378, \mathrm{P}<0.0001)$ as well as age and diastolic BP $(\mathrm{r}=0.197, \mathrm{P}=0.001)$.

Conclusion: A high percentage of the studied population $(31 \%)$ had undiagnosed hypertension and proteinuria (29.7\%). Community screening for these disabling non communicable diseases and lifestyle modifications should be encouraged.

\footnotetext{
* Corresponding Author; Renal Unit, Department of Medicine, Obafemi Awolowo University / Teaching Hospitals Complex, P.M.B 5538 Ile-Ife, Osun State, Nigeria; E mail: fatiuaro@oauife.edu.ng
}

Keywords: Africans; Blacks; Hypertension; Kidney Disease; Proteinuria; ESRD

\section{The authors declared no conflict of interest}

\section{Introduction}

The prevalence of hypertension and chronic kidney disease (CKD) have increased exponentially in both the developing and developed countries in the last decade [1-3]. Hypertension is recognised to be a cause as well as a complication of CKD $[4,5]$. While the prevalence of hypertension in rural and urban communities in Nigeria varies between $12-32.8 \%$ in different studies, the prevalence of CKD is still largely speculative as data is just emerging $[1,3,6,7]$. The majority of patients with CKD undergo a progressive decline of renal function over years before requiring renal replacement therapy which is largely unafforadable in developing countries $[1,4,5]$. Hypertension and proteinuria are important risk factors for further deterioration in renal function irrespective of the cause of CKD [8, 9]. Furthermore, studies have established that interventions that decrease blood pressure (BP) level in patients with proteinuria and renal insufficiency consistently delay the progression of CKD [8-11]. As a result of the poor outlook of CKD in developing countries, which is particularly worse in subSaharan Africa, the International Society of Nephrology (ISN), Commission for the Global Advancement of Nephrology (ISN-COMGAN) now reffered to as ISN Global Outreach Programs has made the fight against CKD one of its major priorities. These programs focus on promoting awareness, early detection and effective treatment as outlined by the Bellagio conference [12]. In a bid to create awareness of kidney disease, its causes and preventive strategies, we organised health education and screening in different populations in Nigeria as a way of commemorating World Kidney Day (WKD). This is a day set aside by the International Federation for Kidney Foundations (IFKF) and International Society of 
Table 1: Distribution of proteinuria and glycosuria according to blood pressure category

\begin{tabular}{|c|c|c|c|c|}
\hline & Normal BP & Stage-1 HTN & Stage-2 HTN & $P$ value \\
\hline \multicolumn{5}{|c|}{ Presence of proteinuria } \\
\hline Negative & $140(78.7 \%)$ & $38(55.1 \%)$ & $23(59 \%)$ & 0.0001 \\
\hline Positive & $38(21.3 \%)$ & $31(44.9 \%)$ & $16(41 \%)$ & \\
\hline \multicolumn{5}{|c|}{ Presence of glycosuria } \\
\hline Negative & $172(96.6 \%)$ & $63(91.3 \%)$ & $38(97.4 \%)$ & 0.01 \\
\hline Positive & $6 \quad(3.4 \%)$ & $6(8.7 \%)$ & $1(2.6 \%)$ & \\
\hline
\end{tabular}

Nephrology (ISN) on the second Thursday in the month of March every year. A major aspect of our WKD activities is screening for kidney disease or its markers and factors predisposing to it. On the $12^{\text {th }}$ March 2009, we conducted health education, free medical examination and screening among a market population in Ile-Ife as part of the World Kidney Day celebration. Our objective was to define (if any) the magnitude of undiagnosed hypertension and proteinuria in this market population and assess factors that may influence both, including anthropometric indices. This study was presented at the Hypertension Teaching Seminar and International Federation for Hypertension in Africa conference held in Abuja in 2009.

\section{Methods}

All participants were recruited after an informed consent. They were taken through a brief medical history and had their sociodemographic data recorded. The BP was measured on the left arm using a mercury sphygmomanometer (Accoson, England) at heart level using appropriate cuff size. The subjects were allowed to relax for 3-5 minutes in a sitting position before assessment of BP. Hypertension was defined as a systolic blood pressure $\geq 140 \mathrm{mmHg}$ or diastolic blood pressure $\geq 90 \mathrm{mmHg}$ and/or commitant use of antihypertensive medications by self report [7]. Blood Pressure was categorized according to the Seventh Joint National Committee Report on Detection, Evaluation and treatment of High Blood pressure [7]. The categories were as follows; normal: systolic BP (SBP) $<120$ and diastolic BP (DBP) of $<80 \mathrm{mmHg}$, prehypertension: SBP 120-139 or DBP 80-89 mmHg, stage-1: SBP 140 -159 or DBP $90-99 \mathrm{mmHg}$ and stage- 2 : $\mathrm{SBP} \geq 160$ or $\mathrm{DBP} \geq 100 \mathrm{mmHg}$.

Subjects were instructed on modality of collecting midstream urine specimen. Menstruating females were excluded from urinalysis. The participants thereafter provided urine samples which were tested using urinary medi-test Combi 2 test strips (Macherey-Nagel, Germany). Blood glucaose was not assessed as the majority of participants had taken breakfast before the screening.

Weights were taken using bathroom scale (Hana Weighing Scale, China) after removal of shoes and heavy clothings, while the heights were recorded using stadiometer. The body mass index (BMI) was calculated from the measured weight (in kilograms) and height (in meters) and was categorized as not obese (BMI $\left.<25 \mathrm{~kg} / \mathrm{m}^{2}\right)$, overweight $\left(\mathrm{BMI}=25-29.9 \mathrm{~kg} / \mathrm{m}^{2}\right)$ or obese $\left(\mathrm{BMI} \geq 30 \mathrm{~kg} / \mathrm{m}^{2}\right)$ according to the $2000 \mathrm{WHO}$ criteria [13].

Data was analysed using SPSS package version 16. Results are presented as frequencies and proportions or mean \pm SD. Chi-square and Fishers exact tests were used for comparison of data where appropriate. Bivariate linear regression analysis was used to determine the association between anthropometric parameters and hypertension. $\mathrm{P}$ value $<0.05$ indicated statistical significance.

\section{Results}

A total of 286 participants were screened. Their age ranged between $13-90$ years (mean $\pm \mathrm{SD} ; 49.5 \pm 15.7$ ). There was female preponderance with 278 of participants $(90.2 \%)$ being females. Systolic and diastolic blood pressures ranged between 90-220 $\mathrm{mmHg}$ and 50-120 $\mathrm{mmHg}$ respectively. One-hundred and eight participants (37.7\%) had hypertension out of which only $20(6.7 \%)$ were previously diagnosed. Sixty nine (24.1\%) of participants had stage-1 hypertension while 39 (13.6\%) had stage-2 (JNC VII).

The BMI ranged between 15.6 and $46.6 \mathrm{~kg} / \mathrm{m}^{2}$ (Mean \pm $\left.\mathrm{SD} ; 26.76 \pm 5.28 \mathrm{~kg} / \mathrm{m}^{2}\right)$. Twenty one $(7.4 \%)$ subjects had BMI $<20 \mathrm{~kg} / \mathrm{m}^{2}, 96$ (33.4\%) had BMI between $20-25 \mathrm{~kg} /$ $\mathrm{m}^{2}$ and the remaining $169(59.2 \%)$ of participants had BMI above $25 \mathrm{~kg} / \mathrm{m}^{2}$ (35.6\% of them had BMI between $25-29.9 \mathrm{~kg} / \mathrm{m}^{2}$ and $23.6 \%$ had BMI greater than $30 \mathrm{~kg} /$ $\left.\mathrm{m}^{2}\right)$.

Eighty-five participants (29.7\%) had proteinuria while only $13(4.5 \%)$ had glycosuria. A significantly 
Figure 1: Correlation between age (years) and BMI (kg/m²) $(\mathrm{r}=\mathbf{0 . 1 7 1}, \mathrm{P}=\mathbf{0 . 0 0 4})$

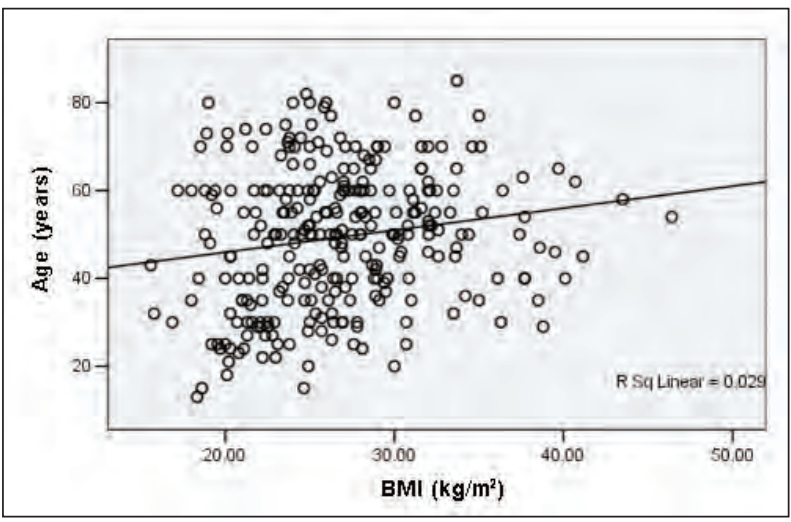

Figure 2: Correlation between age (years) and systolic BP $(\mathrm{mmHg})(\mathrm{r}=\mathbf{0 . 3 7 8}, \mathrm{P}=\mathbf{0 . 0 0 0 1})$

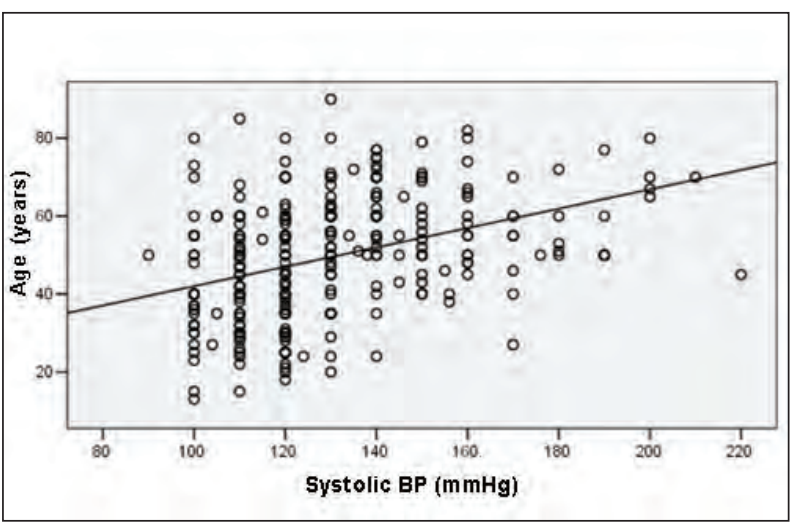

Figure 3: Correlation between age (years) and diastolic BP $(\mathrm{mmHg})(\mathrm{r}=\mathbf{0 . 1 9 7}, \mathrm{P}=\mathbf{0 . 0 0 1})$

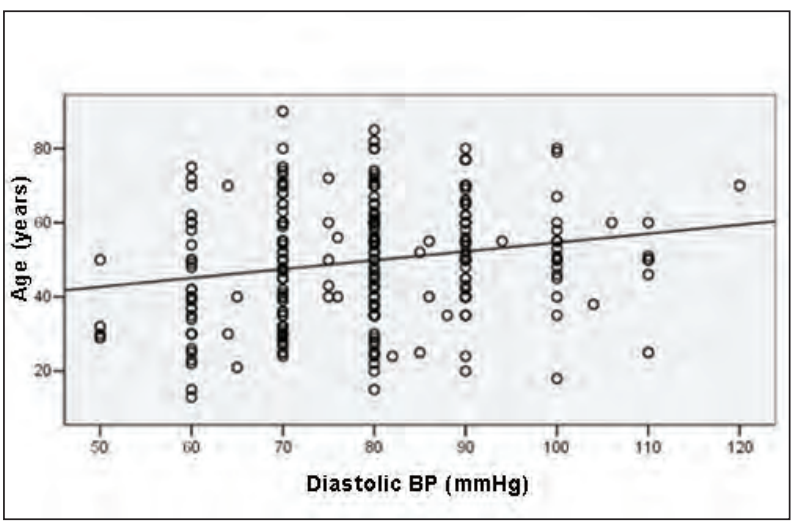

higher percentage of participants with stage-1 and stage-2 hypertension had proteinuria compared with non-hypertensive subjects (Table-1). Similarly a significantly higher percentage of participants with stage-1 hypertension had glycosuria compared with non- hypertensive participants $(\mathrm{P}=0.01)($ Table- 1$)$. There was a significant positive correlation between age and BMI $(\mathrm{r}=0.171, \mathrm{P}=0.004)$, age and systolic $\mathrm{BP}(\mathrm{r}=0.378$, $\mathrm{P}<0.0001)$ as well as age and diastolic BP $(\mathrm{r}=0.197$, $\mathrm{P}=0.001)$ (Figures 1-3).

\section{Discussion}

Hypertension and CKD are assuming epidemic proportions globally and both contribute significantly to cardiovascular morbidity and mortality in developed and developing economies [1-11]. Prevalence of hypertension in Nigeria varies between 12 and $32.8 \%$ in available data sources and one third of hypertensive subjects are unaware of their hypertensive status [3, 6, 7]. About 38\% of participants in this study had hypertension which was severe in $14 \%$. Our findings are in agreement with the findings of Ulasi et al [7] who found a prevalence of hypertension of $32.8 \%$ in their population based survey. These figures are higher than earlier reports from this environment and this may probably be a consequence of the high prevalence of overweight and obese subjects in both study populations. The National non-communicable disease survey conducted about 18 years ago revealed a prevalence of $12 \%$ which is significantly lower than the prevalence found in this study [14]. Our figures and those of Oladapo et al [6] in western Nigeria and Ulasi et al [7] in eastern part of the country suggest that the prevalence of hypertension in our environment is increasing.

Chronic kidney disease not only predisposes to ESRD but also imposes a huge cardiovascular disease burden which is one of the leading causes of death in CKD patients all over the world $[5,15,16]$. A number of factors have been shown to be associated with CKD, these include, ageing, hypertension, impaired glucose tolerance or diabetes mellitus, dyslipidemia, obesity and smoking [17-24]. An interventional approach that would prevent the development and progression of CKD at a community level would thus involve the control of all these factors simultaneously, the so called multi-hit hypothesis. The high prevalence of undiagnosed and untreated hypertension in this study is a clarion call for institution of efforts towards prevention of hypertension and its risk factors even in our rural and semi-urban populations. This would on the long term contribute to reduction in CKD burden and its associated cardiovascular risk $[17,18]$.

In addition, this study demonstrated that about a third of screened subjects had proteinuria which worsened with the severity of hypertension. Some earlier studies have documented that subjects with macroproteinuria are the groups at high risk of cardiovascular disease and CKD progression [25-32]. Identifying individuals in the early stages of CKD with proteinuria is of utmost importance, 
especially as there is strong evidence that the CVD risk associated with stages 1 and 2 is nearly equal to that of stage 3 CKD [25].

The finding that elevated BP, both SBP and DBP were associated with proteinuria was not unexpected as the relationship between hypertension and CKD has been well established [5, 29, 30]. In addition, hypertensive nephrosclerosis is one of the leading causes of ESRD in our environment [33]. The Multiple Risk Factor Interventional Trial (MRFIT) [5] clearly established the fact that hypertension leads to chronic kidney damage. In another analysis of MRFIT data after 10 year follow-up, it was shown that for every $9 \mathrm{mmHg}$ increase in DBP, there was an associated odd ratio of 1.37 for the presence of dipstick-positive proteinuria [28]. Elevated intraglomerular pressure which results in glomerulosclerosis and eventual increased protein trafficking has been suggested as the mechanism responsible for proteinuria in hypertension [28, 29]. This study also established that age positively correlated with BMI and BP. The age dependent increase in BP may be partly due to age dependent vascular sclerosis, glomerulosclerosis and salt sensitivity [4, 5, 17, 30-32]. Previous data have supported the hypothesis that increasing age is associated with increasing susceptibility to the effects of dietary sodium on BP [30].The ability of the kidney to excrete a salt load decreases with age, therefore older people may respond to high salt load with a greater increase in BP [30, 31]. This was also corroborated by a Kenyan longitudinal study, in which subjects were followed up for 18 months and there was a significant increase in BP with advancing age; in addition, older subjects had a greater increase in BP than younger ones [32]. The relationship between BMI and BP might be potentially confounded by dietary salt intake and physical activity level, both of which are difficult to standardize and measure across different ethnic groups. However, the risk of hypertension has been reported to be higher among groups with overweight and obesity in previous studies [7, 8, 34, 35].

\section{Conclusion}

This study demonstrated the high prevalence of undiagnosed hypertension and proteinuria in this market population. Age significantly correlated with BMI and BP. Therefore, community screening for these potentially disabling non-communicable diseases as well as institution of lifestyle modification should be encouraged. Strict control of BP and proteinuria is consequently recommended as the bedrock for prevention of CKD and its progression.

\section{References}

1. Arogundade FA, Barsoum RS. Chronic Kidney Disease (CKD) Prevention in Sub Saharan Africa (SSA): A call for governmental, non governmental and community support. American Journal of Kidney Disease. 2008; $51: 515-23$

2. Chobanian AV, Bakris GL, Black HR, Cushman WC, Green LA, Izzo JL Jr, Jones DW, Materson BJ, Oparil S, Wright JT Jr, Roccella EJ; National Heart, Lung, and Blood Institute Joint National Committee on Prevention, Detection, Evaluation, and Treatment of High Blood Pressure; National High Blood Pressure Education Program Coordinating Committee. The Seventh Report of the Joint National Committee on Prevention, Detection, Evaluation, and Treatment of High Blood Pressure: the JNC 7 report. JAMA. 2003 May 21;289(19):2560-7.

3. Cooper R, Rotimi C, Ataman S, McGee D, Osotimehin B, Kadiri S, Muna W, Kingue S, Fraser H, Forrester T, Bennett F, Wilks R. The prevalence of hypertension in seven populations of west African origin. Am J Public Health. 1997 Feb;87(2):160-8.

4. Klahr S, Schreiner G, Ichikawa I. The progression of renal disease. N Engl J Med 1988;318:1657-66.

5. Klag MJ, Whelton PK, Randall BL, Neaton JD, Brancati FL, Ford CE, Shulman NB, Stamler J. Blood pressure and end-stage renal disease in men. N Engl J Med. 1996 Jan 4;334(1):13-8.

6. Oladapo OO, Salako L, Sodiq O, Shoyinka K, Adedapo K, Falase AO. A prevalence of cardiometabolic risk factors among a rural Yoruba south-western Nigerian population: a population-based survey. Cardiovasc J Afr. 2010;21(1):26-31.

7. Ulasi II, Ijoma CK, Onodugo OD. A community-based study of hypertension and cardio-metabolic syndrome in semi-urban and rural communities in Nigeria. BMC Health Serv Res. 2010;10:71.

8. Brenner BM. Remission of renal disease: recounting the challenge, acquiring the goal. $\mathrm{J}$ Clin Invest. 2002;110:1753-8.

9. Peterson JC, Adler S, Burkart JM, Greene T, Hebert LA, Hunsicker LG, King AJ, Klahr S, Massry SG, Seifter JL. Blood pressure control, proteinuria and the progression of renal disease. The modification of Diet in Renal disease study, Ann Intern Med.1995;123:754-62.

10. Jafar TH, Stark PC, Schmid CH, Landa M, Maschio G, de jong PE, de Zeeuw D, Shahinfar S, Toto R, Levey AS. Progression of chronic kidney disease: the role of blood 
pressure control, proteinuria and angiotensin-converting enzyme inhibitor: a patient-level meta-analysis. Ann Intern Med.2003; 139:244-52.

11. Anavekar NS, McMurray JJ, Velazquez EJ, Solomon SD, Kober L, Rouleau JL, White HD, Nordlander R, Maggioni A, Dickstein K, Zelenkofske S, Leimberger JD, Califf RM, Pfeffer MA. Relation between renal dysfunction and cardiovascular outcomes after myocardial infarction. N Engl J Med. 2004 Sep 23;351(13):128595.

12. Dirks JH, de Zeeuw D, Agarwal SK, Atkins RC, Correa-Rotter R, D’Amico G, Bennett PH, El Nahas M, Valdes RH, Kaseje D, Katz IJ, Naicker S, Rodriguez-Iturbe B, Schieppati A, Shaheen F, Sitthi-Amorn C, Solez K, Viberti G, Remuzzi G, Weening JJ; International Society of Nephrology Commission for the Global Advancement of Nephrology Study Group 2004. Prevention of chronic kidney and vascular disease: toward global health equity-the Bellagio 2004 Declaration. Kidney Int Suppl. 2005 Sep;(98):S1-6.

13. WHO. The problem of overweight and obesity 2000 : Prevention and managing the global epidemic. In: Report series 894 wt. Geneva. WHO; 2000. p.537.

14. Akinkugbe OO. Non communicable disease in Nigeria. Final Report of National Survey. Lagos: Federal Ministry of Health; 1997. p.1-118.

15. Levey AS, Coresh J, Balk E, Kausz AT, Levin A, Steffes MW, Hogg RJ, Perrone RD, Lau J, Eknoyan G; National Kidney Foundation. National Kidney Foundation practice guidelines for chronic kidney disease: evaluation, classification, and stratification. Ann Intern Med. 2003 Jul 15;139(2):137-47. Erratum in: Ann Intern Med. 2003 Oct 7;139(7):605.

16. Imai E, Horio M, Iseki $\mathrm{K}$, Yamagata $\mathrm{K}$, Watanabe T, Hara S, Ura N, Kiyohara Y, Hirakata H, Moriyama $\mathrm{T}$, Ando $\mathrm{Y}$, Nitta $\mathrm{K}$, Inaguma D, Narita I, Iso H, Wakai K, Yasuda Y, Tsukamoto Y, Ito S, Makino H, Hishida A, Matsuo S. Prevalence of chronic kidney disease (CKD) in the Japanese general population predicted by the MDRD equation modified by a Japanese coefficient. Clin Exp Nephrol. 2007 Jun;11(2):156-63.

17. Iseki K, Iseki C, Ikemiya Y, Kunjo K, Takishita S. Risk of developing low glomerular filtration rate or elevated serum creatinine in a screened cohort in Okinawa. Japan. Hypertens Res. 2007; 30(2):167-74.

18. Chen J, Muntner P, Hamm LL, Jones DW, Batuman V, Fonseca V. The metabolic syndrome and chronic kidney disease in US adults. Ann Intern Med. 2004; 140(3):167174

19. Hallan S, de Mutsert R, Carlsen S, DekkerFW, Aasarød $\mathrm{K}$, Holmen J. Obesity, smoking, and physical inactivity as risk factors for CKD: are men more vulnerable? Am J Kidney Dis. 2006;47(3):396-405.

20. Kubo M, Kiyohara Y, Kato I, Iwamoto H, Nakayama K, Hirakata H, Fujishima M. Effect of hyperinsulinemia on renal function in a general Japanese population: the Hisayama study. Kidney Int. 1999 Jun;55(6):2450-6.

21. Nguyen S, Hsu CY. Excess weight as a risk factor for kidney failure. Curr Opin Nephrol. Hypertens. 2007;16(2):71-6.

22. Krammer H, Luke A, Bidani A, Cao G, McGee D. Obesity and prevalent and incident of CKD: the hypertension Detection and follow up program. Am J Kidney Dis. 2005;2005;46(4):587-94.

23. Yamagata K, Ishida K, Sairenchi T, Takahashi H, Ohba S, Shiigai T, Narita M, Koyama A. Risk factors for chronic kidney disease in a community-based population: a 10-year follow-up study. Kidney Int. 2007 Jan;71(2):159-66.

24. De jong PE, Velde M van der, Gansevoort RT, Zoccali C. Screening for Chronic Kidney disease: where does Europe go? Clin J Am Nephrol.2008,3(2):616-23.

25. Glassock RJ. Winearls C. Screening for CKD with EGFR: doubts and danger. Clin J Am Soc Nephrol. 2008,3(5):1563-8.

26. Hallan SI, Dahl K, Oien CM, Grootendorst DC, Aasberg A, Holmen J, Dekker FW. Screening strategies for chronic kidney disease in the general population: follow-up of cross sectional health survey. BMJ 2006,333(7577):1047.

27. United State Renal Data System: International comparisons of ESRD. In : USRDS 1999 Annual Data Report. Bethesda (MD): National Institute of Health, National institute of Diabetes and Digestive and Kidney Diseases; 1999. p. 25-38.

28. Grimmin RH, Svendsen KH, Kasiske B, Keane WF, Wahi MM, for the MRFIT Research Groups. Proteinuria is a risk factor for mortality over 10 years follow up. Kidney Int. 1997; 52(suppl 63):S10-S14.

29. Bianchi S, Bigazzi R, Campese VM: Microalbuminuria in essential hypertension: significance, pathophysiology and therapeutic implications. Am J Kidney Dis. 1999; 34:973-995. 
30. Shannon RP, Minaker KL, Rowe JW. The influence of age on water balance in man. Semin Nephrol. 1984; 4: 346-353.

31. Avolio AP, Deng FQ, Li WQ, Luo YF, Huang ZD, Xing LF, O'Rourke MF. Effects of aging on arterial distensibility in populations with high and low prevalence of hypertension: comparison between urban and rural communities in China. Circulation. 1985 Feb;71(2):20210 .

32. Poulter N, Khaw KT, Hop wood BEC, Mugambi M, Peart WS, Sever PS. Salt and blood pressure in various population. J Cardiovasc Pharmacol. 1984;6: S197-S203.
33. Adelekun TA, Akinsola A. Hypertension induced chronic renal failure: clinical features, management and prognosis. West Afr J Med. 1998;17(2):104-8.

34. Kadiri S, Walker O, Salako BL, Akinkugbe O. Bloodpressure, hypertension and correlates in urbanized workers in Ibadan, Nigeria: a revisit. J Hum Hypertens. 1999; 13: 23-27.

35. 35. Njelekela M, Negishi H, Nara Y, Tomohiro M, Kuga S, Noguchi T, Kanda T, Yamori M, Mashalla Y, Jian Liu L, Mtabaji J, Ikeda K, Yamori Y. Cardiovascular risk factors in Tanzania: a revisit. Acta Trop. 2001 Jun 22;79(3):231-9. 